\title{
Biodiversity of Lactobacillus plantarum from traditional Italian wines
}

\author{
Bruno Testa $\cdot$ Silvia Jane Lombardi $\cdot$ Patrizio Tremonte $\cdot$ \\ Mariantonietta Succi • Luca Tipaldi - Gianfranco Pannella • \\ Elena Sorrentino $\cdot$ Massimo Iorizzo $\cdot$ Raffaele Coppola
}

Received: 13 January 2014/ Accepted: 15 April 2014/Published online: 10 May 2014

(C) The Author(s) 2014. This article is published with open access at Springerlink.com

\begin{abstract}
In this study, 23 samples of traditional wines produced in Southern Italy were subjected to microbiological analyses with the aim to identify and biotype the predominant species of lactic acid bacilli. For this purpose, a multiple approach, consisting in the application of both phenotypic (API 50CHL test) and biomolecular methods (polymerase chain reaction-denaturing gradient gel electrophoresis and 16S rRNA gene sequencing) was used. The results showed that Lactobacillus plantarum was the predominant species, whereas $L$ b. brevis was detected in lower amount. In detail, out of 80 isolates 58 were ascribable to Lb. plantarum and 22 to Lb. brevis. Randomly amplified polymorphic DNA-polymerase chain reaction was used to highlight intraspecific variability among $L b$. plantarum strains. Interestingly, the cluster analysis evidenced a relationship between different biotypes of Lb. plantarum and their origin, in terms of wine variety. Data acquired in this work show the possibility to obtain several malolactic fermentation starter cultures, composed by different $L b$. plantarum biotypes, for their proper use in winemaking processes which are distinctive for each wine.
\end{abstract}

Keywords Lactobacillus plantarum . Wine . PCR-DGGE · RAPD-PCR · Malolactic fermentation

B. Testa $\cdot$ S. J. Lombardi $\cdot$ P. Tremonte $\cdot$ M. Succi .

L. Tipaldi · E. Sorrentino - M. Iorizzo $(\square) \cdot$ R. Coppola Department of Agricultural, Environmental and Food Sciences (DiAAA), University of Molise, via De Sanctis snc, 86100 Campobasso, Italy

e-mail: iorizzo@unimol.it

\section{G. Pannella}

School of Agricultural, Forest and Environmental Science, University of Basilicata, Viale dell'Ateneo Lucano 10 , 85100 Potenza, Italy

\section{Introduction}

Malolactic fermentation (MLF) is considered a desirable transformation in winemaking processes for the production of some important red wines. It is a deacidification process consisting in the decarboxylation of L-malic acid by the malolactic enzyme and it is a result of the metabolic activity of some lactic acid bacteria (LAB). Nowadays, the use of LAB strains as malolactic starter cultures to improve the wine quality is a common practice in winemaking. Oenococcus oeni is probably the best adapted species and it is able to overcome the harsh environmental wine conditions, and therefore this species represents the widespread commercial ML starter culture (Bartowsky and Borneman 2011; Lombardi et al. 2012; Cafaro et al. 2013). However, other LAB species possess many favourable characteristics that would make them suitable candidates for their use as ML starters (du Toit et al. 2011). Among them, several Lactobacillus species not only display the ability to survive the harsh wine conditions (Mañes-Lázaro et al. 2009; Izquierdo et al. 2009; Pozo-Bayón et al. 2009; Ruiz et al. 2010), but they also possess enzymes involved in the MLF (Matthews et al. 2007; De Las Rivas et al. 2009). Lb. plantarum could be the best candidate for its use in winemaking processes, since it is able to survive under the stress conditions of winemaking $(\mathrm{pH} 2.8-3.4$, alcohol 11-15\%), and to drive the MLF. Moreover, some $L b$. plantarum strains are able to inhibit spoilage bacteria and to degrade biogenic amines (Capozzi et al. 2010, du Toit et al. 2011). These evidences found confirmation in the practical application of a $L b$. plantarum strain used as commercial starter culture, recently released by Lallemand, to ensure MLF in musts or wines (Fumi et al. 2010). However, several reports highlighted that the success of MLF starters depends on the used strain and it is influenced 
by several factors, including the geographical origin of the strain (Gonzàlez-Arenzana et al. 2012), as well as the adaptability to the winemaking processes distinctive for each wine. Moreover, individual strains of Lb. plantarum have been found to produce distinctive flavours, and the concentration of some volatile compounds seems to be influenced by the LAB species or the LAB strain, thus reflecting a degree of diversity among strains of the same species (Pozo-Bayón et al. 2005). On these bases, the present work was planned to identify and biotype different $L b$. plantarum strains naturally occurring in traditional wines from Southern Italy for their next use as proper ML starter cultures in different winemaking processes.

\section{Materials and methods}

Wine samples

Twenty-three samples of wine were collected from different artisanal wineries located in various areas of Southern Italy. None of the artisanal wineries had ever used LAB commercial starter cultures. One fermentation tank was sampled in each winery when the alcoholic fermentation was completed and the wines underwent spontaneous MLF with the endogenous microbiota. Wine samples were then aseptically taken for physico-chemical and microbiological analyses during MLF.

Physico-chemical and microbiological analyses

Total acidity, $\mathrm{pH}$ and alcohol were determined according to the EC Official Methods (1999). LAB were enumerated and isolated by plating serial decimal dilutions on MRS agar (Oxoid) adding $40 \mathrm{mg} / \mathrm{l}$ of cicloheximide to inhibit the yeast growth. Plates were incubated at $28{ }^{\circ} \mathrm{C}$ for $72 \mathrm{~h}$ under anaerobic conditions using an anaerobic system (Oxoid). Five to ten colonies were picked randomly from MRS plates at the highest dilution having positive growth, excluding those with a number of colonies $<30$ c.f.u./ml. The purified isolates were maintained frozen at $-80{ }^{\circ} \mathrm{C}$ in MRS medium with $15 \%$ glycerol.

Identification

Gram staining, catalase test, microscope observation, study of metabolism (Lafon-Lafourcade et al. 1983), assimilation of carbon sources by the API 50CHL test (bioMerieux), were used to screen the isolates as described by López et al. (2008) and to presumptively identify those belonging to the Lactobacillus genus.
Isolates presumptively identified as $L b$. plantarum were then identified by PCR-DGGE and 16S rRNA gene sequencing and those identified as $L b$. plantarum were biotyped by RAPD-PCR.

DNA extraction and purification from pure culture

Two milliliters of each overnight culture was centrifuged at $14,000 \mathrm{~g}$ for $10 \mathrm{~min}$ at $4{ }^{\circ} \mathrm{C}$ to pellet the cells and the pellet was subjected to DNA extraction according to Querol et al. (1992), with the addition of lysozyme $(25 \mathrm{mg} / \mathrm{ml}$, Sigma) and mutanolysin $(10 \mathrm{U} / \mathrm{ml}$, Sigma) for bacterial cell-wall digestion. Quantity and purity of the DNA were assessed by optical reading at 260 and $280 \mathrm{~nm}$, as described by Sambrook et al. (1989).

DGGE analysis

The DNA from each strain was prepared for DGGE by amplifying the V1 region of 16S rRNA using the following primers: P1V1 (5'-GCG GCG TGC CTA ATA CAT GC$3^{\prime}$ ) (Cocolin et al. 2001) and P2V1 (5'-TTC CCC ACG CGT TAC TCA CC-3') (Rantsiou et al. 2005). A GC clamp (5' CGC CCG CCG CGC CCC GCG CCC GTC CCG CCG CCC CCG CCC G-3') (Sheffield et al. 1989) was attached to the $5^{\prime}$ end of the P1V1 primer. PCR was performed in a Mastercycler gradient (Eppendorf). The reaction mixture $(50 \mu)$ consisted of $10 \mathrm{mmol} / \mathrm{l}$ Tris- $\mathrm{HCl}(\mathrm{pH} \quad 8.3)$, $50 \mathrm{mmol} / \mathrm{l} \mathrm{KCl}, 200 \mu \mathrm{mol} / \mathrm{l}$ of each dATP, dGTP, dCTP and dTTP, $1.5 \mathrm{mmol} / 1 \mathrm{MgCl}, 0.2 \mu \mathrm{mol} / \mathrm{l}$ of each primer, $200 \mathrm{ng}$ DNA and 1.25 U Taq-DNA polymerase (Finnzymes). The amplification program consisted of a $1 \mathrm{~min}$ denaturation step at $95{ }^{\circ} \mathrm{C}$, a $1 \mathrm{~min}$ annealing step at $45{ }^{\circ} \mathrm{C}$ and a 1 min extension step at $72{ }^{\circ} \mathrm{C}$. The first cycle was preceded by an initial step at $95^{\circ} \mathrm{C}$ for $5 \mathrm{~min}$. After 35 cycles, there was a final 7 min extension step at $72{ }^{\circ} \mathrm{C}$. Negative controls without DNA template were included in parallel. PCR products were separated in $1.5 \%(\mathrm{w} / \mathrm{v})$ agarose gel (Sigma) by electrophoresis for $45 \mathrm{~min}$ at $120 \mathrm{~V}$ in TBE $0.5 \mathrm{x}$ (Sigma) and were subsequently visualised by UV illumination after ethidium bromide $(50 \mu \mathrm{g} / \mathrm{ml})$ staining (Sigma). PCR products obtained from amplification of V1 region of 16S rRNA were subjected to DGGE analysis, using a DCode Universal Mutation Detection System (BioRad, Hercules, CA, USA). Electrophoresis was performed in a $0.8-\mathrm{mm}$ polyacrylamide gel $(8 \%$ [w/v] acrylamide-bisacrylamide [37.5:1]) by using two different ranges of denaturant to optimise separation of the products. Two denaturant gradients, from 40 to $60 \%$ (100\% denaturant was $7 \mathrm{M}$ urea plus $40 \%$ [w/v] formamide) increasing in the direction of electrophoresis run, were used. The gels were subjected to a constant voltage of $120 \mathrm{~V}$ for $5 \mathrm{~h}$ at $60{ }^{\circ} \mathrm{C}$, and after electrophoresis they were 
stained for $20 \mathrm{~min}$ in $1.25 \times \mathrm{TAE}$ containing $50 \mu \mathrm{g} / \mathrm{ml}$ ethidium bromide and visualised under UV illumination. DGGE gels were digitally captured by GEL DOC XR System (Bio-Rad, Hercules, CA, USA) using the software Quantity One Analysis (Bio-Rad) and analysed with the pattern analysis software package, Gel Compare II Version 2.0 (Applied Maths, Kortrijk, Belgium). Calculation of similarities in the profiles of bands was based on Pearson product-moment correlation coefficient. Dendrograms were obtained by mean of the Unweighted Pair Group Method using Arithmetic Average (UPGMA) clustering algorithm (Vauterin and Vauterin 1992).

\section{Sequence analysis}

Two to four representative $L b$. plantarum strains for each cluster obtained by DGGE analysis were amplified with primers P1 (5'-GCGGCGTGCCTAATACATGC-3') and P4 (5'-ATCTACGCATTTCACCGCTAC-3'), as described by Klijn et al. (1991), targeting $700 \mathrm{bp}$ of the V1-V3 region of the $16 \mathrm{~S}$ rRNA gene. After purification, (QIAquick PCR purification kit, QIAGEN GmbH, Hilden), products were sent to a commercial facility for sequencing (Eurofins MWG Biotech Company, Ebersberg, Germany). Sequences were aligned with those in GeneBank with the
Blast program (Altschul et al. 1997) to determine the closest known relatives, based on the partial 16S rRNA gene homology.

\section{RAPD-PCR}

Amplification reactions were performed in a $25 \mu \mathrm{l}$ reaction volume containing $10 \mathrm{mmol} / \mathrm{l}$ Tris- $\mathrm{HCl}(\mathrm{pH} 8.3), 50 \mathrm{mmol} / \mathrm{l}$ $\mathrm{KCl}, 200 \mu \mathrm{mol} / \mathrm{l}$ of each dATP, dGTP, dCTP and dTTP, $1.5 \mathrm{mmol} / \mathrm{M} \mathrm{MgCl} 2,1 \mu \mathrm{mol} / \mathrm{l}$ primer, $80 \mathrm{ng}$ DNA and $1.25 \mathrm{U}$ Taq-DNA polymerase (Finnzymes, Finland). A Mastercycler gradient (Eppendorf, Hamburg, Germany) was used with the following primers and amplification conditions: (a) M13: 5'GAGGGTGGCGGTTCT3' (Huey and Hall 1989); the amplification was carried out for 35 cycles of $94{ }^{\circ} \mathrm{C}$ for $1 \mathrm{~min}, 40{ }^{\circ} \mathrm{C}$ for $20 \mathrm{~s}$, ramp to $72{ }^{\circ} \mathrm{C}$ at $0.5{ }^{\circ} \mathrm{C} / \mathrm{s}$, $72{ }^{\circ} \mathrm{C}$ for $2 \mathrm{~min}$; (b) D8635: $5^{\prime}$-GAGCGGCCAAAGGG AGCAGAC-3' (Akopyanz et al. 1992); after an initial step of $94{ }^{\circ} \mathrm{C}$ for 2 min the amplification was performed for 35 cycles of $94{ }^{\circ} \mathrm{C}$ for $1 \mathrm{~min}, 42^{\circ} \mathrm{C}$ for $1 \mathrm{~min}, 72^{\circ} \mathrm{C}$ for $1 \mathrm{~min}$ and $30 \mathrm{~s}$, and a final step at $72{ }^{\circ} \mathrm{C}$ for $10 \mathrm{~min}$.

The amplification products were separated by electrophoresis on $1.5 \%$ (w/v) agarose gel (Sigma-Aldrich, Steinheim, Germany) in $0.5 \times$ TBE buffer and then subjected to ethidium bromide staining. RAPD-PCR gels were
Table 1 Physico-chemical and microbiological features of 23 traditional red wine samples from Southern Italy

${ }^{\mathrm{a}} \mathrm{g} / \mathrm{l} ;{ }^{\mathrm{b}}$ c.f.u./ml

\begin{tabular}{|c|c|c|c|c|c|c|c|}
\hline Sample & Type of wine & Localities & $\mathrm{pH}$ & Alcohol & L-Malic acid $^{\mathrm{a}}$ & L-Lactic acid $^{\mathrm{a}}$ & $\mathrm{MRS}^{\mathrm{b}}$ \\
\hline AG1 & Aglianico & Campania & 3.88 & 13.6 & 0.1 & 2.3 & $6.5 \times 10^{4}$ \\
\hline AG2 & Aglianico & Campania & 3.71 & 13.6 & 0.8 & 2.1 & $5.0 \times 10^{4}$ \\
\hline MT1 & Montepulciano & Molise & 3.68 & 13.5 & 0.9 & 1.9 & $6.0 \times 10^{3}$ \\
\hline MT2 & Montepulciano & Molise & 3.70 & 13.3 & 0.6 & 1.4 & $4.0 \times 10^{3}$ \\
\hline MT3 & Montepulciano & Molise & 3.65 & 11.2 & 0.5 & 2.2 & $3.3 \times 10^{3}$ \\
\hline MT4 & Montepulciano & Molise & 3.60 & 11.2 & 1.2 & 2.4 & $5.5 \times 10^{5}$ \\
\hline MT5 & Montepulciano & Molise & 3.79 & 11.8 & 1.1 & 2.5 & $5.8 \times 10^{5}$ \\
\hline MT6 & Montepulciano & Molise & 3.80 & 11.8 & 1.4 & 2.3 & $4.8 \times 10^{6}$ \\
\hline PI1 & Pentro d'Isernia & Molise & 3.77 & 11.3 & 1.3 & 1.8 & $2.4 \times 105$ \\
\hline PI2 & Pentro d'Isernia & Molise & 3.76 & 11.6 & 0.7 & 1.6 & $2.2 \times 10^{3}$ \\
\hline PD1 & Piedirosso & Campania & 3.68 & 12.6 & 0.4 & 1.9 & $7.8 \times 10^{3}$ \\
\hline PD2 & Piedirosso & Campania & 3.62 & 12.4 & 0.6 & 1.8 & $7.5 \times 10^{3}$ \\
\hline PD3 & Piedirosso & Campania & 3.65 & 12.8 & 0.4 & 2.1 & $6.8 \times 10^{3}$ \\
\hline RM1 & Rosso Molise & Molise & 3.62 & 12.5 & 0.9 & 1.6 & $9.8 \times 10^{3}$ \\
\hline RM2 & Rosso Molise & Molise & 3.80 & 12.1 & 1.6 & 2.3 & $1.2 \times 10^{5}$ \\
\hline TA1 & Taurasi & Campania & 3.76 & 14.2 & 1.5 & 1.8 & $2.3 \times 10^{3}$ \\
\hline TA2 & Taurasi & Campania & 3.69 & 14.1 & 1.4 & 1.9 & $4.3 \times 10^{3}$ \\
\hline TI1 & Tintilia & Molise & 3.54 & 14.6 & 0.2 & 1.9 & $8.8 \times 10^{5}$ \\
\hline TI2 & Tintilia & Molise & 3.86 & 14.2 & 0.4 & 2.2 & $3.4 \times 10^{5}$ \\
\hline TI3 & Tintilia & Molise & 3.76 & 14.0 & 0.6 & 1.9 & $4.5 \times 105$ \\
\hline TI4 & Tintilia & Molise & 3.86 & 14.3 & 0.7 & 1.5 & $2.8 \times 10^{4}$ \\
\hline TI5 & Tintilia & Molise & 3.80 & 14.0 & 0.3 & 1.3 & $6.6 \times 10^{5}$ \\
\hline TI6 & Tintilia & Molise & 3.70 & 14.4 & 0.8 & 1.8 & $8.9 \times 10^{4}$ \\
\hline
\end{tabular}


digitally captured and analysed as previously described for DGGE analysis.

\section{Results}

Physico-chemical and microbiological analyses of wine

The physico-chemical and microbiological features of wine samples are reported in Table 1. Samples were characterized by $\mathrm{pH}$ values ranging from 3.54 (sample TI1) to 3.88 (sample AG1). These values comply those of the typical wines traditionally produced in Southern Italy (Gambuti et al. 2007; Suzzi et al. 2012). The highest alcohol levels were appreciated in Aglianico, Taurasi and Tintilia samples, while the highest levels of acidity were detected in Tintilia and Montepulciano samples.

Microbiological analyses evidenced the presence of lactic acid bacteria (LAB) at levels ranging from $2.2 \times 10^{3}$ c.f.u./ml (sample PI2) to $4.8 \times 10^{6}$ c.f.u./ml (sample MT6). The differences in physico-chemical and microbiological parameters appreciated in this study are common in wines, also deriving from the same geographical area, since several factors, including the grape variety, the age of wines, the environmental conditions can influence the wine features (du Toit et al. 2011).

Phenotypic and molecular identification

Out of 184 isolates, $80 \mathrm{Gram}$ positive, catalase-negative and rod-shaped microorganisms were presumptively identified as lactobacilli and were subjected to API 50CHL identification. According to the species description in Bergey's
Manual (Kandler and Weiss 1986), the phenotypic results highlighted that 22 isolates were ascribable to Lb. brevis, and 58 to $L b$. plantarum (Table 2). However, some doubts were raised for the identification of $4 \mathrm{Lb}$. plantarum strains: API $50 \mathrm{CHL}$ profiles suggested the assignation to this species at only $62 \%$ similarity level. The real identity of the 58 presumptive $L b$. plantarum strains was confirmed by PCRDGGE analysis (Fig. 1). The strains were grouped according to the migration profiles into 6 clusters. For each cluster, 2-4 strains were subjected to sequencing for identification purposes. The results of the sequencing (Table 3) allowed the identification of all the 18 selected strains. Combining these results with those obtained from the DGGE cluster analysis, it was possible to identify all the 58 strains as $L b$. plantarum, which were subsequently characterised through RAPD-PCR analysis (Fig. 2). On the basis of RAPD-PCR band profiles, the assayed $L b$. plantarum strains were divided into 12 clusters. Clusters A ( 9 strains), B (4 strains), C (4 strains), and D (1 strain) grouped all the strains isolated from Montepulciano wines; all the $8 \mathrm{Lb}$. plantarum strains from Piedirosso and Pentro d'Isernia wines were grouped into cluster E; the 5 strains from Aglianico wines were grouped into cluster $\mathrm{F}$, and those (5 strains) from Rosso Molise into cluster G; clusters $\mathrm{H}$ and $\mathrm{I}$ grouped $8 \mathrm{Lb}$. plantarum strains from Taurasi wines, and clusters J, K and L those (14 strains) from Tintilia wines.

\section{Discussion}

Results of physico-chemical and microbiological analyses evidenced that red wines traditionally produced in Southern Italy are characterised by low $\mathrm{pH}$ values and high
Table 2 Preliminary identification and API 50CHL identification of 80 lactobacilli isolated from 23 traditional red wine samples from Southern Italy (strains were grouped on the basis of similar API profiles)

a The preliminary identification was obtained by Gram staining, catalase test, microscope observation and study of metabolism

\begin{tabular}{|c|c|c|c|c|}
\hline Wine origin & $\begin{array}{l}\text { Number } \\
\text { of strains }\end{array}$ & $\begin{array}{l}\text { Preliminary } \\
\text { identification }^{\mathrm{a}}\end{array}$ & $\begin{array}{l}\text { Identification } \\
\text { by API50 CHL }\end{array}$ & $\begin{array}{l}\text { Quality of identification } \\
\text { by API50 CHL }\end{array}$ \\
\hline $\mathrm{MT}, \mathrm{PD}, \mathrm{TA}$ & 6 strains & Lb. plantarum & Lb. plantarum & Excellent \\
\hline AG, MT, TI & 7 strains & Lb. plantarum & Lb. plantarum & Excellent \\
\hline MT, TA & 4 strains & Doubtful & Lb. plantarum & Doubtful \\
\hline AG, MT, TA & 5 strains & Lb. plantarum & Lb. plantarum & Excellent \\
\hline MT, PD & 5 strains & Lb. plantarum & Lb. plantarum & Excellent \\
\hline MT, RI & 6 strains & Lb. plantarum & Lb. plantarum & Excellent \\
\hline RM, TI, TA & 8 strains & Lb. plantarum & Lb. plantarum & Excellent \\
\hline MT, PD, PI, TI & 8 strains & Lb. plantarum & Lb. plantarum & Excellent \\
\hline MT, TI, TA & 11 strains & Lb. plantarum & Lb. plantarum & Excellent \\
\hline MT, PI, PD & 4 strains & Lb. brevis & Lb. brevis & Excellent \\
\hline MT, PD & 3 strains & Lb. brevis & Lb. brevis & Very good \\
\hline PI, PD, RM & 4 strains & Lb. brevis & Lb. brevis & Good \\
\hline $\mathrm{AG}, \mathrm{MT}$ & 3 strains & Lb. brevis & Lb. brevis & Excellent \\
\hline RM, PI & 4 strains & Lb. brevis & Lb. brevis & Very good \\
\hline $\mathrm{AG}, \mathrm{MT}, \mathrm{PD}$ & 4 strains & Lb. brevis & Lb. brevis & Good \\
\hline
\end{tabular}




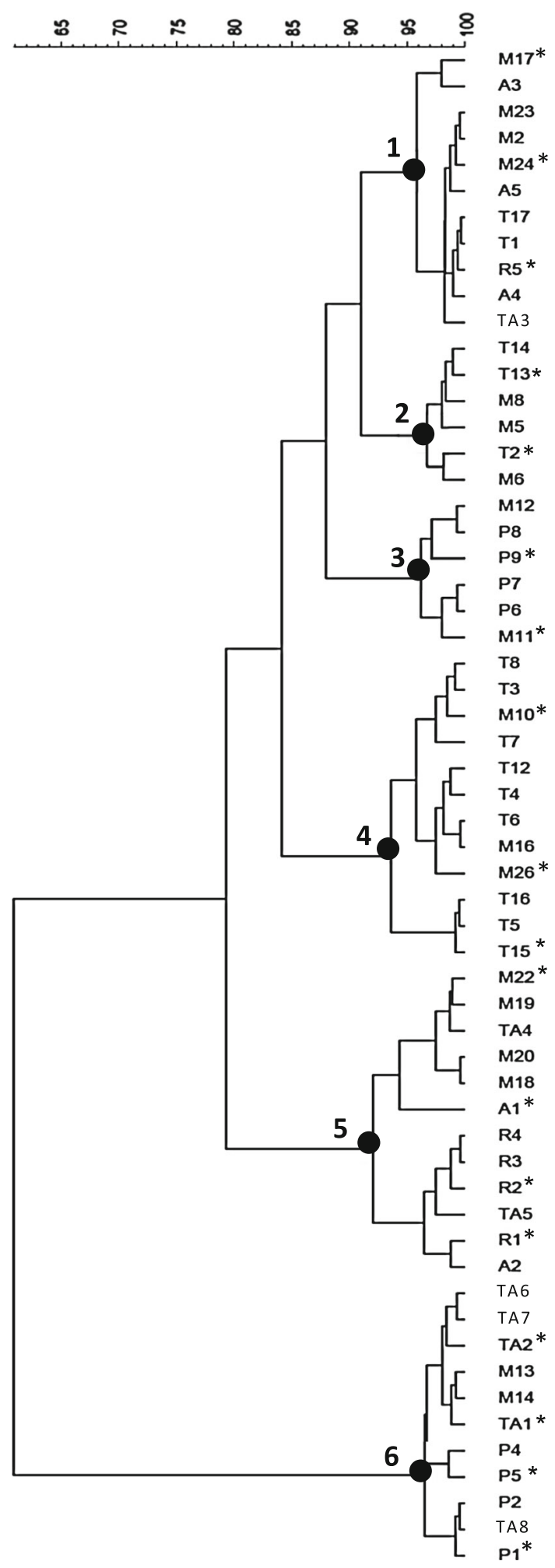

Fig. 1 Dendrogram showing PCR-DGGE profiles of 58 lactobacilli isolated from 23 traditional red wine samples from Southern Italy

alcohol levels, both contributing to the creation of an adverse environment where only few species of lactic acid bacilli are able to survive. Among them, high resistant
Table 3 Identification, based on blast comparison in GenBank, of 18 lactic acid bacilli selected on the basis of DGGE cluster analysis

\begin{tabular}{llllll}
\hline Cluster & Strain & Size & Closest relative & \% Identity & Source $^{\text {a }}$ \\
\hline 1 & M17 & 664 & Lb. plantarum & 100 & GU138574 \\
& M24 & 584 & Lb. plantarum & 100 & GQ922601 \\
& R5 & 635 & Lb. plantarum & 99 & JQ278711.1 \\
2 & T13 & 634 & Lb. plantarum & 100 & JF728278.1 \\
& T2 & 636 & Lb. plantarum & 100 & JF728278.1 \\
3 & P9 & 636 & Lb. plantarum & 100 & JQ278711.1 \\
& M11 & 635 & Lb. plantarum & 100 & JQ278711.1 \\
4 & M10 & 667 & Lb. plantarum & 99 & FJ915780 \\
& M26 & 650 & Lb. plantarum & 99 & GU138574 \\
& T15 & 616 & Lb. plantarum & 99 & JQ278711.1 \\
5 & M22 & 481 & Lb. plantarum & 99 & JQ278711.1 \\
& A1 & 634 & Lb. plantarum & 100 & GU138574 \\
& R2 & 636 & Lb. plantarum & 100 & JQ278711.1 \\
& R1 & 634 & Lb. plantarum & 100 & JQ278711.1 \\
& TA2 & 635 & Lb. plantarum & 99 & AB112083.1 \\
6 & TA1 & 637 & Lb. plantarum & 99 & AB112083.1 \\
& P5 & 611 & Lb. plantarum & 99 & GU299081.1 \\
& P1 & 611 & Lb. plantarum & 99 & GU299081.1 \\
\hline \multirow{4}{*}{ 6 } & & &
\end{tabular}

a Accession number of the sequence of the closest relative found by blast search

species are able to form colonies on culture media, whereas others enter in a viable but non culturable state, as a response to environmental stresses (Divol and LonvaudFunel 2005). In our work, Lb. plantarum was the main species isolated from MRS agar plates, and this fact underlines its high tolerance to low $\mathrm{pH}$ and high alcohol content. In detail, $L b$. plantarum was found in association with Lb. brevis in Aglianico, Montepulciano, Pentro d'Isernia, Piedirosso and Rosso Molise wines, whereas it was the sole species found in Tintilia and Taurasi wines, characterised by the highest alcohol level (Francesca et al. 2014; Iorizzo et al. 2014).

The results obtained in this study underline the usefulness of molecular methods to describe the presence and biodiversity of $L b$. plantarum in traditional wines. In detail, if PCR-DGGE analysis and 16S rRNA gene sequencing can be considered by now suitable tools to identify lactobacilli from wines (Bokulich et al. 2012; Ivey and Phister 2011), RAPD-PCR technique revealed an unexpected biodiversity among $L b$. plantarum strains isolated from different wines. In fact, at the least 12 different biotypes were individuated, and a relationship between the different Lb. plantarum biotypes and their origin, in terms of wine type, was observed.

Different Authors already emphasized the predominance of $L b$. plantarum after alcoholic fermentation and during MLF in wine samples (Beneduce et al. 2004; Spano et al. 


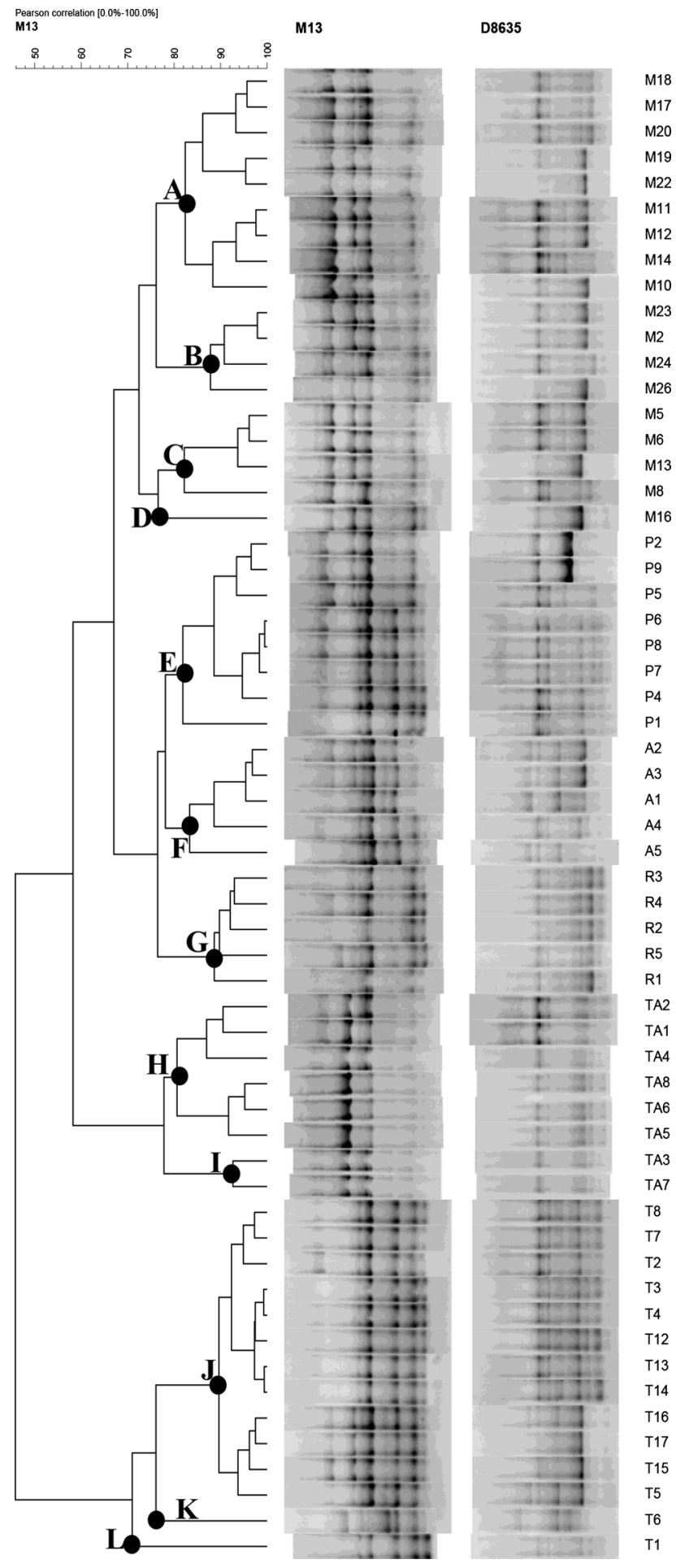

Fig. 2 Dendrogram showing RAPD-PCR profiles of $58 \mathrm{Lb}$. plantarum strains isolated from 23 traditional red wine samples from Southern Italy

2007; Ruiz et al. 2010). Based on these evidences, the application of $L b$. plantarum as co-inoculant in grape must or as inoculant after alcoholic fermentation should be promoted, not only because of its ability to survive under wine conditions, but also for the ability of certain suitable strains to bring correctly the biological deacidification of red wines. In this connection, it is significant that many wine-associated $L b$. plantarum strains are equipped with genes encoding for the enzymes involved in the MLF and several enzymes are active under winemaking conditions (Grimaldi et al. 2005; De las Rivas et al. 2009; du Toit et al. 2011). Also, Lb. plantarum shows a more diverse enzymatic profile than $O$. oeni (Matthews et al. 2007; Mtshali et al. 2010), and some Authors suggested that this feature could play an important role in the modification of the wine aroma profile (Swiegers et al. 2005; Lerm et al. 2011).

Previous findings suggest that $\mathrm{Lb}$. plantarum based starter cultures for MLF in traditional wines can be properly formulated considering the wine-type and/or its geographical area of origin, so the results obtained in the present study represent the starting point to select different biotypes of $L b$. plantarum that will be assayed for their specific technological attitude for each wine type. Moreover, the diversity of $L b$. plantarum strains associated with the wine-type suggests their potential application as fingerprinting tools to ensure the traceability and the authentication of traditional red wine. This last topic represents a crucial issue that, in the last years, stimulated the interest of both producers and researchers to protect wines from adulteration practices (Kokkinofta et al. 2014).

Open Access This article is distributed under the terms of the Creative Commons Attribution License which permits any use, distribution, and reproduction in any medium, provided the original author(s) and the source are credited.

\section{References}

Akopyanz N, Bukanov NO, Westblom TU, Kresovich S, Berg DE (1992) DNA diversity among clinical isolates of Helicobacter pylori detected by PCR based RAPD fingerprinting. Nucleic Acids Res 20:5137-5142

Altschul SF, Madden TL, Shaffer AA, Zhang J, Zhang Z, Miller W, Lipman DJ (1997) Gapped BLAST and PSI-BLAST: a new generation of protein database search programs. Nucleic Acids Res 25:3389-3402

Bartowsky EJ, Borneman AR (2011) Genomic variations of Oenococcus oeni strains and the potential to impact on malolactic fermentation and aroma compounds in wine. Appl Microbiol Biotechnol 92:44-447

Beneduce L, Spano G, Vernile A, Tarantino D, Massa S (2004) Molecular characterization of lactic acid populations associated with wine spoilage. J Basic Microbiol 44:10-16

Bokulich NA, Bamforth CW, Mills DA (2012) A review of molecular methods for microbial community profiling of beer and wine. J Am Soc Brew Chem 70(3):150-162. ISSN: 0361-0470 CODEN: JSBCD3

Cafaro C, Bonomo MG, Salzano G (2013) Adaptive changes in geranylgeranyl pyrophosphate synthase gene expression level under ethanol stress conditions in Oenococcus oeni. J Appl Microbiol. doi:10.1111/jam.12351 
Capozzi V, Russo P, Beneduce L, Weidmann S, Grieco F, Guzzo J, Spano G (2010) Technological properties of Oenococcus oeni strains isolated from typical southern Italian wines. Lett Appl Microbiol 50:327-334

Cocolin L, Manzano M, Cantoni C, Comi G (2001) Denaturing gradient gel electrophoresis analysis of the 16S rRNA gene V1 region to monitor dynamic changes in the bacterial population during fermentation of Italian sausages. Appl Environ Microbiol 67:5113-5121

De las Rivas B, Rodríguez H, Curiel JA, Landete JM, Munoz R (2009) Molecular screening of wine lactic acid bacteria degrading hydroxycinnamic acids. J Agric Food Chem 57:490-494

Divol B, Lonvaud-Funel A (2005) Evidence for viable but nonculturable yeasts in botrytis-affected wine. J Appl Microbiol 99:85-93

du Toit M, Engelbrecht L, Lerm E, Krieger-Weber S (2011) Lactobacillus: the next generation of malolactic fermentation starter cultures - an overview. Food Bioprocess Technol 4:876-906

European Community (1999) Commission Regulation No 761/1999 of 12 April 1999 amending Regulation (EEC) No 2676/90 determining Community methods for the analysis of wines. Off $\mathbf{J}$ Eur Commun. Regulation 761/1999, 4-14

Francesca N, Romano R, Sannino C, Le Grottaglie L, Settanni L, Moschetti G (2014) Evolution of microbiological and chemical parameters during red wine making with extended post-fermentation maceration. Int J Food Microbiol 171:84-93

Fumi MD, Krieger-Weber S, Déléris-Bou M, Silva A, du Toit M (2010) A new generation of malolactic starter cultures for high $\mathrm{pH}$ wines. Proceedings international IVIF congress, WB3 Microorganisms-Malolactic-Fermentation

Gambuti A, Strollo D, Erbaggio A, Lecce L, Moio L (2007) Effect of winemaking practices on color indexes and selected bioactive Phenolics of Aglianico wine. J Food Sci 72:623-628

Gonzàlez-Arenzana L, Santamaría P, López R, Tenario C, LópezAlfaro I (2012) Ecology of indigenous lactic acid bacteria along different winemaking processes of Tempranillo red wine from La Rioja (Spain). Sci World J. doi:10.1100/2012/796327

Grimaldi A, Bartowsky E, Jiranek V (2005) Screening of Lactobacillus spp. and Pediococcus spp. for glycosidase activities that are important in oenology. J Appl Microbiol 99:1061-1069

Huey B, Hall J (1989) Hypervariable DNA fingerprinting in Escherichia coli. Minisatellite probe from bacteriophage M13. J Bacteriol 171:2528-2532

Iorizzo M, Macciolla V, Testa B, Lombardi SJ, De Leonardis A (2014) A physiochemical and sensory characteristics of red wines from the rediscovered autochthonous Tintilia grapevine grown in the Molise region (Italy). Eur Food Res Technol. doi:10.1007/s00217-014-2186-z

Ivey ML, Phister TG (2011) Detection and identification of microorganisms in wine: a review of molecular techniques. J Ind Microbiol Biotechnol 38:1619-1634. doi:10.1007/s10295-011-1020-x

Izquierdo PM, Ruiz P, Seseña S, Palop ML (2009) Ecological study of lactic acid microbiota isolated from Tempranillo wines of Castilla-La Mancha. J Biosci Bioeng 108:220-224

Kandler O, Weiss N (1986) Genus Lactobacillus. In: Sneath PHA, Mair NS, Sharpe ME, Holt JG (eds) Bergey's manual of systematic bacteriology, vol 2. The Williams and Wilkins Company, Baltimore, pp 1209-1234

Klijn N, Weerkamp AH, de Vos WM (1991) Identification of mesophilic lactic acid bacteria by using polymerase chain reaction amplified variable regions of 16S rRNA and specific DNA probes. Appl Environ Microbiol 57:3390-3393

Kokkinofta R, Economidou N, Tzioni E, Damianou K, Poulli K, Savvidou C, Louka C, Kanari P (2014) Studies on the authenticity of local wines by spectroscopic and chemometric analysis. J Chem Chem Eng 8:101-107
Lafon-Lafourcade S, Carre E, Ribéreau-Gayon P (1983) Occurrence of lactic acid bacteria during the different stages of vinification and conservation of wines. Appl Environ Microbiol 46(4):874-880

Lerm E, Endgelbrecht L, du Toit M (2011) Selection and characterisation of Oenococcus oeni and Lactobacillus plantarum South African wine isolates for use as malolactic fermentation starter cultures. S Afr J Enol Vitic 32:280-295

Lombardi SJ, Tremonte P, Succi M, Testa B, Pannella G, Tipaldi L, Sorrentino E, Coppola R, Iorizzo M (2012) Effect of phenolic compounds on the growth and L-malic acid metabolism of Oenococcus oeni. J Life Sci 6:1225-1231

López I, López R, Santamaría P, Torres C, Ruiz-Larrea F (2008) Performance of malolactic fermentation by inoculation of selected Lactobacillus plantarum and Oenococcus oeni strains isolated from Rioja red wines. Vitis 47:123-129

Mañes-Lázaro R, Ferrer S, Rosselló-Mora R, Pardo I (2009) Lactobacillus oeni sp. nov., from wine. Int J Syst Evol Microbiol 59:2010-2014

Matthews A, Grbin PR, Jiranek V (2007) Biochemical characterisation of the esterase activities of wine lactic acid bacteria. Appl Microbiol Biotechnol 77:329-337

Mtshali PS, Divol B, van Rensburg P, du Toit M (2010) Genetic screening of wine-related enzymes in Lactobacillus species isolated from South African wines. J Appl Microbiol 108:1389-1397

Pozo-Bayón MA, G-Alegría E, Polo MC, Tenorio C, Martín-Álvarez PJ, Calvo De La Banda MT, Ruiz-Larrea F, Moreno-Arribas MV (2005) Wine volatile and amino acid composition after malolactic fermentation: effect of Oenococcus oeni and Lactobacillus plantarum starter cultures. J Agric Food Chem 53:8729-8735

Pozo-Bayón MÁ, Pardo I, Ferrer S, Moreno-Arribas MV (2009) Molecular approaches for the identification and characterisation of oenological lactic acid bacteria. Afric $\mathrm{J}$ Biotechnol 8:3995-4001

Querol A, Barrio E, Ramon D (1992) A comparative study of different methods of yeast strains characterization. Syst Appl Microbiol 15:439-446

Rantsiou K, Urso R, Iacumin L, Cantoni P, Cattaneo G, Comi G, Cocolin L (2005) Culture dependent and-independent methods to investigate the microbial ecology of Italian fermented sausage. Appl Environ Microbiol 71:1977-1986

Ruiz P, Izquierdo PM, Seseña S, Palop ML (2010) Analysis of lactic acid bacteria populations during spontaneous malolactic fermentation of Tempranillo wines at five wineries during two consecutive vintages. Food Control 21:70-75

Sambrook J, Fritsch EF, Maniatis T (1989) Molecular cloning: a laboratory manual, 2nd edn. Cold Spring Harbor Laboratory, New York

Sheffield VC, Cox DR, Lerman LS, Myers RM (1989) Attachment of a 40-base pairs $\mathrm{G}+\mathrm{C}$ rich sequence ( $\mathrm{GC}$ clamp) to genomic DNA fragments by the polymerase chain reaction results in improved detection of single-base changes. Proc Natl Acad Sci USA 86:297-303

Spano G, Massa S, Arena ME, Manca de Nadra MC (2007) Arginine metabolism in wine Lactobacillus plantarum: in vitro activities of the enzymes arginine deiminase (ADI) and ornithine transcarbamilase (OTCase). Ann Microbiol 57(1):67-70

Suzzi G, Arfelli G, Schirone M, Corsetti A, Perpetuini G, Tofalo R (2012) Effect of grape indigenous Saccharomyces cerevisiae strains on Montepulciano d'Abruzzo red wine quality. Food Res Int 46:22-29

Swiegers JH, Bartowsky EJ, Henschke PA, Pretorius IS (2005) Yeast and bacterial modulation of wine aroma and flavour. Aust $\mathbf{J}$ Grape Wine R 11:139-173

Vauterin L, Vauterin P (1992) Computer-aided objective comparison of electrophoretic patterns for grouping and identification of microorganisms. Eur Microbiol 1:37-41 